\title{
Climate Change and Childhood
}

\author{
Guddi Singh BA, MB BChir, MPH, MRCPCH, EADTM\&H \\ Paediatric Registrar \\ Guy's \& St.Thomas' NHS Foundation Trust, UK \\ @DrGuddiSingh \\ guddi.singh@nhs.net
}

Key words

Climate change, childhood,

Cite as: Singh G. Climate change and childhood. Sushruta 2020 (Jul) vol 13; issue 2: ePub http://www.sushruta.net

Version 2- received 09.04.20

When I was a child, I was a proud member of the World Wildlife Fund for Nature. I would pore over my issued green wallet and the gleaming silver-gold coins with endangered species imprinted where the Queen's head should be. Saving the world was a noble goal, and as a young person, I was earnest about it.

Today, as a practicing paediatrician, I see it less as a quaint interest than a matter of life and death. In the two and a half decades since I first worried about deforestation and species extinction, my worst fears have come true. Humanity has wiped out $60 \%$ of animal populations since 1970 and up to half of all mature tropical forests since $1950^{1}$. At this rate, extraordinary creatures like tigers and rhinos will inhabit only our myths. The generation before mine ignored the unfolding crisis, and focused instead on economic growth at all costs: churning out mountains of needless stuff, and throwing that stuff away, burning ever-more fossil fuels in the process. My generation could have changed things, but we were lulled into complacency, as fashion became faster, products more dispensable and far-flung countries easier to fly to.

We knew about the dangers of climate change as early as the 1950s, and yet did nothing to reduce emissions. Industry knew, our governments knew, the environmentalists knew - everyone knew. And we all still know. We know that the coming transformations of our planet may well undermine the very possibility of civilisation. And we know that the coming changes will be worse for our children, and worse yet still for their children, whose lives - our actions have demonstrated - mean nothing to us. We have failed to appreciate the danger, and we have failed to act. We have failed to put aside our own interests for those who come after us.

As a paediatrician, the real tragedy is in prognosticating the health of children in the warming years to come. As the WHO-Unicef-Lancet commission ${ }^{2}$ asks, is there "A future for the world's children?" What kinds of lives will they eke out on a planet scorched and scarred? Are we expecting them to play in gardens turned to deserts? To climb the charred remains of trees? To eat from tins where we used to pluck fresh fruit? Instead of a carefree, creative existence, they will migrate long distances in search of a safe home. But safety will be hard to find. A climate-changed world is a conflict-ridden one with mass displacement triggered by rising sea levels and desertification, putting pressure on the few places still hospitable to life. In 2016 the number of malnourished people in the world reached over 2 billion. ${ }^{3}$ If the near future promises population increase, food shortage and nutrient collapse what number will this rise to? 
As temperatures rise, malaria, dengue and Lyme disease will spread. In overcrowded conditions, diseases once considered vanquished - such as TB and cholera - will return emboldened. Much of the progress that medical science has made on these fronts could be wiped out in a single generation.

This is not hyperbole; in a wicked twist of injustice, those living in the nations that have contributed least to this crisis - Bangladesh, Ethiopia and the small island nations - are at this very moment facing situations just like those described. How long before the entire world's children suffer the same fate?

The dangers to the wellbeing of our children are so considerable it makes me question whether I ought to bring children of my own into such a world. If I did, one thing is certain: I would be enraged. I would not leave the streets or the doors of politicians until someone could give me an answer for why we have been so horribly betrayed.

The Extinction Rebellion and the school climate strikes have brought this crisis to international attention. And yet states' response to protestors has been to arrest them. How dare we imprison those who stand for the future of our children? Politicians criticise climate protests for 'significantly disrupting the lives of others'. But it's only disruption if you're distracted by something else: mindless consumption or endless profit. These protests and climate strikes are not disruption - they are vital.

We have cost our children the earth. It is difficult to look at this fact and not flinch. But doing so illuminates. The danger posed to our children brings into relief a dimension of the crisis that has been largely absent -

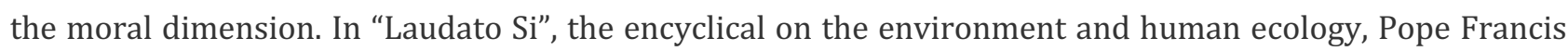
quotes St. Bartholomew: "to commit a crime against the natural world is a crime against ourselves, and a sin against God". ${ }^{4}$ He urges that environmental problems require us to look not just for technological solutions but for a change at the very heart of humanity - otherwise we are dealing merely with symptoms.

I am not a Catholic, but this is a language I can understand. As a doctor, there is no greater threat to the health of my patients than the viability of our heartbreakingly beautiful, fragile, planet Earth. All paediatricians - and arguably all doctors - should be climate activists. We should be standing side-by side with the Extinction Rebellion and with striking children.

Could I have done more to help save the planet as a child? Probably, as Greta Thunberg is demonstrating. ${ }^{5}$ Can I do more to help save it now? Absolutely. And I urge my colleagues to join me. It is easy to complain that the problem is too vast and each of us is too small. But even in the face of overwhelming odds, action is still possible.

For my medical colleagues, there is much we can do. First, we must join calls on our governments to tell the truth about climate change, declare an ecological and climate change emergency and make serious moves to radically reduce emissions. Second, we must lobby to 'green' our medical institutions: to divest from fossil fuels and go plastic-free immediately. Finally - and most essential- we must back a vision for the world that puts planetary health at the centre. We must push for an economic model that does not privilege profit and growth for the few, but that encourages abundance for the many. Such models are being developed as I write. ${ }^{6}$ Models that might, just might, secure a world for our children to inherit.

Everything is changing about the natural world, and everything must change about the way we conduct our lives. The weight of science and morality insists we act, and that we act now.

\section{References}


1. Barrett, M., Belward, A., Bladen, S., Breeze, T., Burgess, N., Butchart, S., ... \& de Carlo, G. (2018). Living planet report 2018: Aiming higher.

2. Clark, H., Coll-Seck, A. M., Banerjee, A., Peterson, S., Dalglish, S. L., Ameratunga, S., ... \& Claeson, M. (2020). A future for the world's children? A WHO-UNICEF-Lancet Commission. The Lancet, 395(10224), 605-658.

3. World Health Organization. (2018). The state of food security and nutrition in the world 2018: building climate resilience for food security and nutrition. Food \& Agriculture Organisation.

4. Francis, P. (2016). Laudato Si': On Care For Our Common Home. Perspectives on Science and Christian Faith, 68(4), 266-268.

5. Thunberg, G. (2019). No one is too small to make a difference. Penguin.

6. Van den Bergh, J. C., \& Kallis, G. (2012). Growth, a-growth or degrowth to stay within planetary boundaries?. Journal of Economic Issues, 46(4), 909-920. 